\title{
Tryptophan Depletion Bioreactor, a New Cancer Therapy
}

\author{
Rolf Bambauer* \\ Formerly Institute for Blood Purification, Homburg/Saar, Germany
}

Submission: October 29, 2017; Published: December 15, 2017

*Corresponding author: Rolf Bambauer, MD, PhD, Frankenstrasse, 466424 Homburg, Tel: 06841/68500; Fax: 06841/68561; Email: rolf.bambauer@t-online.de

Abstract

The cancer therapeutic strategies known to date are not adequate for all cancer patients. Most of them are followed by a high rate of side effects and complications. The L-tryptophan depletion bioreactor is described as a possible new method of cancer therapy. L-tryptophan is an essential amino acid which has been recognized as an important cancer nutrient and its removal can lead to destruction of the tumour. Normal human cells or tumor cells cannot synthesize L-tryptophan and therefore tumor resistance is unlikely to develop. L-tryptophan is also a constituent for different bio-molecules such as Serotonin, Melatonin, and is needed for other synthesis processes in the cell growth. A column which contained TSO as a bioreactor was integrated in a plasmapheresis unit and tested it in different animals. Brest cancer and medulloblastoma showed the greatest efficacy of L-tryptophan degrading. Tryptophan side chain oxydase (TSO) is developed to treat cancer diseases successfully, and has low side effects. A combination of L-tryptophan depletion with all available cancer therapies is possible.

Keywords: L-tryptophan; Tryptophan side chain oxydase (TSO); TSO depletion bioreactor

\section{Introduction}

Approximately $10 \%$ of all malignant diseases in a progressive stage can be cured. A great problem of the most administered chemotherapy regimens is often a development of resistance against different cancers [1,2]. In many cases the resistance exists primarily before the chemotherapy is administered, or the oncogenes of cancer cells can be mutated during the chemotherapy.

The end result is a resistance against the administered chemotherapy

Table 1: Cancer therapy strategy.

New endocrine and cytotoxic therapy like antioestrogene, aromatase inhibitors

and cytotoxic drugs like Taxane, camptothecin analogs, etc.

High dose chemotherapy and stem cell transplantation in leukemia and solide tumours [3]

Cancer vaccines and specific immunotherapy [4]

Antibodies as specific cancer therapy with monoclonal antibodies [5]

Immunotoxins [6]

Human gene therapy [7]

Tyrosine kinase inhibitors [8]

Detection of tumor cell dissemination by immunocytology [9]

Neoangiogenesis and tumour growth [10]

\begin{tabular}{|c|}
\hline IA* with polyclonal ab against sTNFR [11] \\
\hline Transforming the $\mathrm{TA}^{* *}$ into immunologic therapy [12] \\
\hline
\end{tabular}

*IA: Immuno Adsorption; **TA: Therapeutic Apheresis; sTNFR: Tumor Necrosis Factor Receptor

A. A comparable mechanism is observed for the new kinase inhibitors. The cancer cells can change their oncogenes by mutations resulting in resistance against the kinase inhibitors. In these cases new drugs and therapeutic concepts must be developed continuously which are very expansive. In the last years various new sophisticated therapeutic strategies were developed of which some are summarized in Table 1 [3-12]. All the previous cancer therapeutic strategies are not effective in all patients and they are often associated with a high rate of side effects.

B. The high rate of side effects and low effectiveness need the development of new drugs and new therapeutic methods constantly. Various authors reported possibilities of treatment of different cancers with so-called anti-tumor enzymes, bioreactors, as an extracorporeal tumor treatment [13-15]. One possibility is the influence of the protein synthesis by depletion of essential amino acids such as L-Tryptophan [15-18].

The use of serum amino depletion as an effective anticancer agent was first published by Kidd [19,20]. He reported that 
serum of normal guinea pig could induce regression in certain types of animal lymphomas. Subsequently, in 1961 Broome [21] showed that the enzyme L-asparaginase was the anti-neoplastic substance in normal guinea pig serum which depleted the serum of the nonessential amino acid L-asparaginase. The principle of removing amino acids from blood as a form of cancer therapy has proven to be beneficial in cases of acute lymphoblastic leukemia using L-asparaginase to degrade the nonessential amino acid L-asparaginase, constituting an important tumor nutrient. However, L-asparaginase sensitive tumours can eventually become L-asparaginase resistant. This is usually due to the increased denovo synthesis of L-asparaginase by the tumor cells. L-asparaginase is a non-essential amino acid and can be synthesized by the human organism. Roberts et al. $[14,22]$ described the isolation of the L-tryptophan degrading enzyme, indolyl-3-alkane- $\alpha$-hydroxylase, later shown to consist of 2 isoenzymes and called tryptophan side chain oxydase (TSO $1,2)$. Blood tryptophan depletion by TSO resulted in a significant anti-neoplastic activity against mouse tumours in vivo.

\section{Methods}

Treatment of certain tumours by deprivation of the essential amino acid L-tryptophan has the advantage over non-essential amino acid deprivation, because tumor cells cannot synthesize L-tryptophan $[23,24]$. This offers the potential advantage over non-essential amino acid deprivation because host and tumour cells cannot synthesize L-tryptophan, and tumour resistance is therefore unlikely to develop. L-tryptophan cannot be produced by human or animal cells itself. L-tryptophan is an essential amino acid. L-tryptophan is an important amino acid for the cellular integrity. L-tryptophan is needed for a lot of different metabolic processes.

The exposure of tumor cells to decreased levels of the essential amino acid L-tryptophan offers a potential advantage in tumour treatment, since de novo synthesis cannot occur, therefore preventing tumour resistance. Tumour cells sensitive to L-tryptophan depeltion would repeatedly respond to this form of therapy in contrast to all chemotherapeutic approaches where resistance develops leading to the death of the patients. L-tryptophan is an essential amino acid. A removal of this nutrient from blood cannot overcome by a higher production in the cells, therefore making it possible to treat sensitive tumor cells over and again without the disadvantage of the tumor being able to overcome the "bottle neck" situation of nutrient deprivation [25].

To design a so-called bioreactor for removing the potential cancer nutrient L-tryptophan from blood, the L-tryptophan degrading enzyme tryptophan side chain oxidase 3 (TSO 3) was isolated by Gottfried Schmer [23] and chemically bound to Glutaraldehyd activated gamma amino silane silica and to Zeta affinity micro-columns consisting of a Glutaraldehyd activated polyacrylic-cellulose copolymer. In animal experiments a closed circuit bioreactor in a single pass used. Zeta affinity bioreactors degraded L-tryptophan levels changed little throughout the experiment indicating a vast extra vascular tryphophan pool. The procedures were tolerated well by the animals without any change in vital signs. The TSO-was tested in sheep and rabbits by Schmer [26] with a closed circuit mini plasmapheresis unit. He could show that the L-tryptophan depletion in plasma was $100 \%$ in sheep and 95\% in rabbits by a single pass through the bioreactor. The investigations in immune supprimized rats with tumor like medullonblastoma were in 9/10 animal a strong regression of the tumor in comparison to the control animals. In 20 different tumor cell lines there were some different results. Breast cancer and medulloblastoma showed the greatest efficacy of L-tryptophan degrading. With gamma-interferon all cell lines showed a higher L-tryptophan use and therefore a rapid destruction of all cells.

Enzymatic removal of L-tryptophan from blood of a patient by plasmapheresis and extracorporeal treatment by enzymatic degradation of L-tryptophan in the pheresed blood has long been perceived to have therapeutic benefits. For example, blood levels of L-tryptophan modulate synthesis and synaptic release of the neurotransmitter serotonin. Varying L-tryptophan blood levels provides a means to affect brain serotonin levels. The metabolites which are producing by the L-tryptophan degrading enzymes will be eliminated by the human kidneys.

\section{Discussion}

To treat the cancer successful, a new cancer therapy consisting of the L-tryptophan degrading enzyme, TSO 3, has been developed, which will be won by gene technology from bacterial or fungal sources, TSO. The bioreactor based on Silica. The amino groups containing silica beats were activated with Glutaraldehyd. The activated aminosilane containing silica beats were then washed after different procedures. The activated silica beads can be stored in buffer at $4{ }^{\circ} \mathrm{C}$ and remain fully active for more than 6 weeks. 20 to $30 \mathrm{ml}$ of the activated beads filled in a column, sterilised and inserted in the filtrate line of an apheresis unit. Advantages of the L-tryptophan degrading enzyme TSO 3 are an excellent stability, no development of a resistance to tumor cells and the combination on this new therapy with all other therapy measures especially with gamma interferon [25].

The production of the TSO 3 enzyme by gene technology, production of the columns and sterilization is the first step, than the new cancer therapy could be started in a clinical trial with an apheresis unit after the revised Declaration of Helsinki in different countries. The treatment of 1 circle includes 5-6 treatments per week, daily treatment time 4 to 5 hours and 3 to 4 weeks. The duration of a minimum of 4 hours per day is necessary to keep the L-tryptophan concentration in the blood as low as possible to release L-tryptophan from the vulnerable cells of the tumor. The duration of 1 circle is 4 weeks because a longer treatment can be influenced the L-tryptophan of the 
healthy organs. Another circle can be started again after 2 to 3 months, if no remission is reached. A combination with other cancer therapies is possible. But 1 circle must be sufficient to reduce the tumor and the metastases and reaches a remission. Side effects are very low and are a serotonin deficiency like anxiety, fatigue, cognitive impairment, agitation, chronic pain, feeling worse etc, and side effects due to the extracorporeal blood circulation [25]. A further point is the toxicity of TSO. This point must be clarified with different washing procedures before the introduction of this therapy in humans. Endo-toxins are available only won by Pseudomonas sources. They can be eliminated by different washing procedures or by the gene technology from fungal sources.

For example in Germany alone 400,000 to 480,000 women and men afflict by different cancers per year. Of these patients, $20 \%$ to $30 \%$ die in the first year after diagnosing of the cancer. The therapeutic measures to date have very different results in view point of healing or quality of life, etc. The treatment costs for one therapeutic cycle of L-tryptophan depletion of 3 to 4 weeks depend on the production costs of the column. The costs for 15 to 20 primary separation of the blood and the perfusion of plasma through the bioreactor column are comparable with the costs of the immuno-adsorption. The costs can be reduced by producing TSO from fungal sources and a treatment set of one column for 3-4 weeks per patient and one treatment cycle. If only $0.1 \%-1 \%$ of the new patients who afflict the disease every year will be treated, this would be a great benefit for the patients. The treatment could be repeated after 2 to 3 months or more, if no remission is reached by the first treatment cycle. Between the cycles a staging of the cancer is necessary. A further step could be the development of a direct blood perfusion, and a further important step could be the development of a drug of TZSO 3 for intravenous and/or oral application.

\section{Conflict of Interest}

The author declares no conflicts of interest.

\section{References}

1. Reichle A, Diddens H, Rastetter J, Berdel WE (1991) Resistenzmechanismen maligner Zellen gegenüber Zytostatika. Dtsch Med Wschr 116: 186-191.

2. Volm M, Mattern J, Samsel B (1991) Häufung von zytostaticaresistenten Lungentumoren bei Rauchern. Dtsch Med Wschr 116: 1303-1306.

3. Kanz L (1997) Hochdosistherapie und Stammzell transplantation. Internist 38: 1045.

4. Schirmacher V (1997) Tumorvakzine und aktiv spezifische Immuntherapie. Internist 38(11): 1050-1054.

5. Gramatzki M, Valerius $T$ (1997) Antikörper als spezifische Tumortherapie. Internist 38: 1055.

6. Barth S, Winkler U, Diehl V (1997) Immunotoxine. Internist 38: 1063.
7. Lindemann A, Mertelsmann R (1997) Gentherapie Ein realistischer Ansatz zur Behandlung maligner Erkrankungen? Internist 38(11): $1070-1073$

8. Alves P, Hiddemann W (1997) Thyroxinaseinhibitoren. Internist 38: 1074.

9. Wörmann B, Wulf GG, Griesinger F, Hiddemann W (1997) Sensitiver Nachweis disseminierter Tumorzellen. Prognostische Bedeutung und Therapieansätze. Internist 38(11): 1083-1091.

10. Fiedler W, Gehling U, Mende T, Hossfeld DK (2001) Neoangiogenese und Tumorwachstum. Dtsch Ärztebl 98(21): A 1392.

11. Lentz MR (1993) The role of therapeutic apheresis in the treatment of cancer. A review. Ther Apher 3(1): 40-49.

12. Porrata LF, Markowic SN (2010) Therapeutic apheresis immunologic graft engineering for the treatment of cancer. Transplantationsmedizin 22: $379-382$.

13. Rosenfeld HJ, Watanabe AK, Roberts J (1977) Mechanism of action of indolyl-3-alkane- $\alpha$-hydroxylase. Biol Chem 252(3): 6970-6973.

14. Roberts J Schmid FA, Rosenfeld HJ (1979) Biologic and antineoplastic effects of enzyme-mediated in vivo depletion of L-glutamine, L-tryptophan and L.-histidine. Cancer Treat Rep 63(6): 1045-1054.

15. Cook SJ, Pogson CI, Smith SA (1980) Indoleamine 2,3-dioxygenase. Biochem J 189: 461-466.

16. Schmer G, Chandler WL (1987) Enzyme reactors: achievements, problems, future perspectives. In: Bambauer R, Malchesky PS, Falkenhagen D (Eds.), Therapeutic Plasma Exchange and Selective Plasma Separation. Schattauer Verlag, New York, USA, pp. 437-443.

17. Schmer G, Roberts J (1978) Purification of indolyl-3-alkane- $\alpha$ hydroxylase by affinity chromatography on indolyl-agarose columns. Biochem Biophy Acta 527(1): 264-271.

18. Yoshida R, Park SW, Yasul H, Takikawa O (1988) Tryptophan degration in transplanted tumor cells undergoing rejection. J Immunol 141(8): 12819-2823.

19. Kidd JG (1953) Regression of transplanted lymphomas induced in vivo by means of normal guinea pig serum: I. Cause of transplanted cancers of various kinds in mice and rats given guinea pig serum, horse serum, or rabbit serum. J Exp Med 98(6): 565-582.

20. Kidd JG (1953) Regression of transplanted lymphoma induced in vivo by means of normal guinea pig serum: II. Studies on the nature of the active serum constituent: histological mechanism of regression: tests for effects of guinea pig serum on lymphoma cells in vitro: Discussion. J Exp Med 98(6): 583-606.

21. Broome JD (1961) Evidence that the L-asparaginase activity in guinea pig serum is responsible for its antilymphoma effects. Nature 191: $1114-1115$

22. Roberts J, Rosenfeld HJ (1977) Isolation, Crystallization and Properties of indolyl-3-alkane- $\alpha$-Hydroxylase. J Biol Chem 252: 2640-2647.

23. Schmer G, Roberts J (1979) Molecular engineering of the L-tryptophandepleting enzyme indolyl-3-alkane- $\alpha$-hydroxylase. Canc Treat Rep 63(6): 1123-1126.

24.Schmer G, Dennis MB, Hsueh S, Hou KC (1990) The synthesis of L-trytpophan degrading bioreactors. Int J Artif Org 13: 316-320.

25. Bambauer R (2015) L-Tryptophan depeltion bioreactor: a possible cancer therapy. Am J Exp Clin Res 2(3): 107-112.

26. United States patent No. 5,244,807 "PNDH Enzyme composition and their methods of use," 14.9.1993. 


(C) (1) Commons Attribution 4.0 License

\section{Your next submission with Juniper Publishers} will reach you the below assets

- Quality Editorial service

- Swift Peer Review

- Reprints availability

- E-prints Service

- Manuscript Podcast for convenient understanding

- Global attainment for your research

- Manuscript accessibility in different formats

( Pdf, E-pub, Full Text, Audio)

- Unceasing customer service

Track the below URL for one-step submission https://juniperpublishers.com/online-submission.php 